Arq. Bras. Med. Vet. Zootec., v.66, n.3, p.827-836, 2014

\title{
Intake, milk production and weight change curves for lactating Holstein x Zebu cows under grazing
}

\author{
[Consumo, curvas de lactação e variação de peso de vacas Holandês x Zebu em pastejo] \\ S.A. Santos ${ }^{1}$, S.C. Valadares Filho ${ }^{1}$, E. Detmann ${ }^{1}$, J.R.M. Ruas ${ }^{2}$, L.F. Prados ${ }^{1}$, L.D.S. Mariz ${ }^{1}$ \\ ${ }^{1}$ Universidade Federal de Viçosa - Viçosa, MG \\ ${ }^{2}$ Empresa de Pesquisa Agropecuária de Minas Gerais - Epamig - Felixlândia, MG
}

\begin{abstract}
The purpose of this study was to evaluate feed intake and develop lactation and weight change curves for Holstein x zebu cows under grazing. Eighteen F1 cows were used, divided into three treatments; 6 were Holstein x Gir (HGI), 6 were Holstein x Guzerat (HGU), and another 6 were Holstein x Nelore (HNE), under the feeding conditions of pasture plus concentrate with $22 \%$ of crude protein $(\mathrm{CP})$. To estimate individual feed intake at pasture, 2 markers were used: titanium dioxide to estimate fecal dry matter (DM) excretion, and the indigestible acid detergent fiber (iADF) to estimate individual pasture intake. The Wood (1967) model was used to evaluate milk yield and the parameters were estimated for each genetic group, as follows: HGI $=17.2667 * \mathrm{t}^{0.0652} * \mathrm{e}^{-0.00424 \mathrm{t}} ; \mathrm{HGU}=18.1470 * \mathrm{t}^{0.0332} * \mathrm{e}^{-0.00408 t}$; and $\mathrm{HN}=$ $14.2836 * t^{0.1059 *} \mathrm{e}^{-0.00552 t}$. The NEFA contents varied according to different genetic groups $(\mathrm{P}<0.001)$. It was concluded that the estimated peak DMI occurs during the sixth week of lactation, when the DMI by the different genetic groups was stabilized. The HGI cows have greater cumulative production at 305-d.
\end{abstract}

Keywords: crossbreeding, F1, lactation, tropical grasses

\section{RESUMO}

O objetivo deste estudo foi avaliar o consumo de vacas Holandês x Zebu sob pastejo e desenvolver curvas de lactação e variação de peso para elas. Dezoito vacas F1 foram utilizadas, divididas em três tratamentos: seis foram Holandês x Gir (HGI), seis foram Holandês x Guzerá (HGU, e outras seis foram Holandês $x$ Nelore (HNE), sob as mesmas condições de alimentação com pasto e concentrado com $22 \%$ de proteína bruta $(P B)$. Para estimar o consumo individual, dois indicadores foram utilizados: dióxido de titânio para estimar a excreção de matéria seca fecal (DM), e fibra em detergente ácido indigestível (FDAi) para estimar a ingestão de pasto. O modelo de Wood (1967) foi utilizado para avaliar a produção de leite, e os parâmetros foram estimados para cada grupo genético, conforme a seguir: $H G I=$ $17.2667 * t^{0.0652} * e^{-0.00424 t} ; H G U=18.1470 * t^{0.0332} * e^{-0.00408 t}$; e $H N=14.2836 * t^{0.1059} * e^{-0.00552 t}$. O conteúdo de ácidos graxos não esterificados (AGNE) variou de acordo com os diferentes grupos genéticos $(P<0,001)$. Concluiu-se que o pico estimado para CMS ocorre durante a sexta semana de lactação, quando o CMS pelos diferentes grupos genéticos foi estabilizado. As vacas HGI têm maior produção de leite acumulada aos 305-d.

Palavras-chave: cruzamentos, F1, gramíneas tropicais, lactação

\section{INTRODUCTION}

Tropical countries, which have high average temperatures throughout the year, face challenges in milk production when using

Recebido em 19 de setembro de 2012

Aceito em 20 de dezembro de 2013

*Autor para correspondência (corresponding author)

E-mail: stefanie_zootecnia@hotmail.com

Reserarch project supported by FAPEMIG and INCT Ciência

Animal
European cattle breeds because these animals suffer from heat stress and metabolic changes. Consequently, there is a decrease in feed intake and efficiency, as well as pregnancy rates.

As a result, it is important to study animals that are better adapted to tropical climates. The 
production of F1 crossbred females for dairy farms in this environment normally involves breeding zebu (Bos indicus) females with a Holstein bull to exploit the beneficial effects of heterosis. The zebu breeds most often used are Gir and Guzerat, because these animals possess milk-producing characteristics and are more docile than other zebu breeds. However, there is market discount for heifers birthed by Nelore dams because of a fear of aggressive behavior and lower milk production. Therefore, research is needed to characterize the milk production and performance of these different breed combinations.

In general, zebu breeds are adapted to warmer climates because of their short and fine hairs and dark skin covered with melanin, and increased surface area in the ears and dewlap for heat exchange. Its thermal comfort zone is between 10 and $27^{\circ} \mathrm{C}$ and can be expanded to $5-31^{\circ} \mathrm{C}$ for Bos indicus $\mathrm{x}$ Bos taurus crosses, clearly demonstrating the effects of heterosis (Pereira, 2005). Studies on the performance of zebu cross cows during lactation under grazing conditions are needed; in addition to these factors, tropical C4 grasses are not highly digestible, which results in a lower efficiency of milk production with specialized animals. The objective of this study was to develop feed intake and weight change curves for F1 crossbred Holstein $\mathrm{x}$ zebu cows under grazing systems.

\section{MATERIALS AND METHODS}

The experiment was carried out at the Empresa de Pesquisa Agropecuária de Minas Gerais Research Farm, in Felixlândia-MG-Brazil, between the months of January and May, 2008. The procedures for humane care and handling of the animals followed the recommendations of the Federal University of Viçosa.

In total, there were $18 \mathrm{~F} 1$ cows -6 Holstein $\mathrm{x}$ Gir (HGI), 6 Holstein x Guzerat (HGU) and 6 Holstein $x$ Nelore (HNE) - that formed three experimental treatments with six repetitions. The initial body weight was $560.01 \pm 6.62$ for Holstein $\mathrm{x}$ Nelore; $566.87 \pm 4.70$ for Holstein $\mathrm{x}$ Guzerat and 513.36 \pm 5.42 for Holstein $x$ Gir. Cows were placed into the experiment by their similar lactation numbers, which was four or five, for all genetic groups. The cows had recently calved and were distributed in simple random samples under the same feeding conditions, as follows: pasture plus $220 \mathrm{~g} / \mathrm{kg}$ crude protein (CP) supplement.

Every day after milking (7h00), the cows were led to paddocks of Brachiaria decumbens, under rotational grazing management. Dry matter intake (DMI) and digestible dry matter (DMd) estimates were obtained for 6 experimental periods, each comprising 21 days, and started during the first week of lactation; milk production and weight change were collected until the end of lactation.

To estimate individual feed intake at pasture, 2 markers were used, during 6 experimental periods of 21 days each, with 14 for adaptation, and 7 for data collection. Titanium dioxide was used as a marker to estimate fecal dry matter (DM) excretion. From the $7^{\text {th }}$ to $18^{\text {th }}$ day of the experimental period, $15 \mathrm{~g}$ of titanium dioxide was given via an oral catheter to each cow during the afternoon milking at $15 \mathrm{~h} 00$. There was a total of 11 days of application, being 6 days for stabilization of marker excretion in the feces and 5 days feces collection. Feces were collected twice daily, following each milking. Fecal samples collected were dried, ground and the amount composited proportionately based on the air dry weight per animal. Titanium dioxide concentration was determined using the technique described by Myers et al. (2004).

To determine individual pasture intake, indigestible acid detergent fiber (iADF) was used as an internal marker. To estimate the iADF from the pasture, 2 esophageally fistulated steers were used for the collection of esophageal extrusa on the $16^{\text {th }}$ day of each experimental period. To quantify the $\mathrm{iADF}$ in the feces, concentrate, and extrusa, the samples were placed in Ankom F57 filter bags and incubated in the rumen of a fistulated animal for 264 hours (Casali et al., 2008). The material remaining after the incubation was washed in water and then subjected to acid detergent extraction. The estimates of individual feed intake were determined according to the equation: DMI $(\mathrm{kg} / \mathrm{d})=([($ fecal excretion $* \mathrm{i} A \mathrm{AD}$ concentration in feces) - iADF in concentrate]/iADF concentration in extrusa) + DMI from concentrate. 
Total concentrate (Table 1) was supplied in an individual trough in the milking shed and was supplied according to milk production, providing $1 \mathrm{~kg}$ of concentrate for each $3 \mathrm{~kg}$ of milk produced; the initial production needed to be $8 \mathrm{~kg}$ of milk to receive the initial concentrate. After milking, the feed orts were collected and weighed. The concentrate contained: soybean meal $(240 \mathrm{~g} / \mathrm{kg})$, ground corn $(685 \mathrm{~g} / \mathrm{kg})$, urea $(20 \mathrm{~g} / \mathrm{kg})$, ammonium sulfate $(2 \mathrm{~g} / \mathrm{kg})$, limestone $(16 \mathrm{~g} / \mathrm{kg})$, dicalcium phosphate $(23 \mathrm{~g} / \mathrm{kg})$, sodium chloride $(4 \mathrm{~g} / \mathrm{kg})$, and a mineral premix (10 $\mathrm{g} / \mathrm{kg})$, which contained cobalt sulfate $(79.3 \mathrm{~g} / \mathrm{kg})$, copper sulfate $(239 \mathrm{~g} / \mathrm{kg})$, zinc sulfate $(635 \mathrm{~g} / \mathrm{kg})$, potassium iodide $(31.7 \mathrm{~g} / \mathrm{kg})$ and sodium selenite $(15.8 \mathrm{~g} / \mathrm{kg})$.

Table 1. Bromatological composition of the concentrate, extrusa and pasture allowance throughout the experimental period ${ }^{1}$

\begin{tabular}{|c|c|c|c|c|c|c|c|c|c|c|c|c|c|}
\hline \multirow[b]{2}{*}{ Item $^{2}$} & \multicolumn{2}{|c|}{21 days } & \multicolumn{2}{|c|}{42 days } & \multicolumn{2}{|c|}{63 days } & \multicolumn{2}{|c|}{84 days } & \multicolumn{2}{|c|}{105 days } & \multicolumn{2}{|c|}{126 days } & \multirow[b]{2}{*}{$\mathrm{CONC}$} \\
\hline & EXT & ALW & EXT & ALW & EXT & ALW & EXT & ALW & EXT & ALW & EXT & ALW & \\
\hline $\mathrm{ADM}$ & -- & 3.2 & -- & 4.5 & -- & 6.4 & -- & 6.8 & -- & 6.5 & -- & 10.8 & -- \\
\hline DM & -- & 170.6 & -- & 190.2 & -- & 270.0 & -- & 300.8 & -- & 370.1 & -- & 410.5 & 870.6 \\
\hline $\mathrm{CP}$ & 50.2 & 30.1 & 120.3 & 80.1 & 90.6 & 60.9 & 80.4 & 40.4 & 70.6 & 30.6 & 60.8 & 40.3 & 240.6 \\
\hline NDIN & 6.6 & 4.4 & 9.7 & 12.2 & 8.5 & 9.2 & 7.9 & 6.9 & 9.1 & 6.5 & 10.2 & 6.1 & 79.3 \\
\hline $\mathrm{EE}$ & 21.0 & 5.80 & 19.3 & 9.2 & 15.1 & 7.8 & 19.4 & 8.8 & 20.1 & 15.4 & 22.7 & 12.9 & 28.3 \\
\hline iNDF & 208.0 & 312.9 & 175.2 & 311.2 & 202.5 & 319.0 & 243.2 & 357.2 & 228.6 & 377.6 & 311.1 & 449.9 & 25.6 \\
\hline NFC & 229.0 & 224.5 & 200.4 & 214.3 & 185.4 & 195.2 & 158.1 & 205.2 & 206.6 & 172.4 & 220.8 & 175.7 & 549.2 \\
\hline ADFap & 285.2 & 352.4 & 269.0 & 362.4 & 324.2 & 378.6 & 315.1 & 374.1 & 336.5 & 447.7 & 273.3 & 402.9 & 30.1 \\
\hline LIG & 61.7 & 117.9 & 42.2 & 75.8 & 88.5 & 140.8 & 87.4 & 162.2 & 102.1 & 121.5 & 75.8 & 112.8 & 17.5 \\
\hline
\end{tabular}

${ }^{1}$ EXT - esophageal extrusa; ALW - pasture allowance; CONC - concentrate

${ }^{2} \mathrm{ADM}$ - available dry matter (t/ha); DM - dry matter, g/kg; OM - organic matter, g/kg (dry basis); $\mathrm{CP}$ - crude protein, g/kg (dry basis); NDIN - Neutral detergent insoluble nitrogen, g/kg (\% NDF); EE - Ether extract, g/kg (dry basis); NDFap - neutral detergent fiber corrected for ash and protein, g/kg (dry basis); iNDF - indigestible neutral detergent fiber, g/kg (dry basis) ; NFC non-fiber carbohydrates, g/kg (dry basis); ADF - acid detergent fiber, g/kg (dry basis) ; LIG - lignin, g/kg (dry basis).

All pre-drying was done in a ventilated oven at $60{ }^{\circ} \mathrm{C}$ for $72 \mathrm{~h}$, and grinding was carried out in a mill with $2 \mathrm{~mm}$ mesh sieves. The samples were stored in plastic containers for later analyses of dry matter (DM), organic matter (OM) and crude protein (CP) (AOAC, 1997, method number 934.01 for DM; 930.05 for OM and 981.10 for $\mathrm{CP}$ ). Ether extract (EE) was analyzed by Soxhlet extraction with petroleum ether. The neutral detergent fiber concentrations, corrected for ash and protein (NDFap), and ADFap were determined using the methodology proposed by Mertens (2002) and were analyzed with the addition of thermostable alpha-amylase (Ankom Tech. Corp., Fairport. NY). Lignin was extracted with $72 \%$ sulfuric acid. Neutral detergent insoluble nitrogen (NDIN) was evaluated with the Kjeldahl method (Licitra et al., 1996). Nonfiber carbohydrates, corrected for ash and protein (NFCap), were calculated as proposed by Detmann and Valadares Filho (2010), where: NFCap $=100-([\% \mathrm{CP}-\% \mathrm{CP}$ derived from urea $+\%$ urea $]+\%$ NDFap $+\% \mathrm{EE}+\%$ ash $)$.

Forage collection, to estimate the pasture allowance, was done on the first day of the experiment and on the last day of each experimental period. Samples were collected by cutting 10 randomly chosen locations from each paddock, within a $0.49 \mathrm{~m}^{2}$ metal frame, as described by McMeniman (1997) (Table 1). The cows were mechanically milked at $7 \mathrm{~h} 00$ and $14 \mathrm{~h} 00$, and daily milk production was recorded. To access the BW change, cows were weighed again every 10 days.

Blood samples were collected on $21^{\text {th }}$ day of each experimental period, by coccygeal venipuncture using test tubes with anticoagulants (EDTA), immediately centrifuged at room temperature and $2.800 \times g$ for $15 \mathrm{~min}$, and after the removal of the plasma, packed into glass containers and frozen at $-15^{\circ} \mathrm{C}$, for the subsequent analyses of NEFAs (Non-esterified fatty acids). To determine the NEFAs, a commercial kit (HR Series NEFA-HR(2), Wako Diagnostic, Richmond, VA, USA) was used.

The mathematical model used to fit the lactation curve was: $Y=a t^{b} e^{-c t}$ (Wood, 1967); where $\mathrm{Y}=$ milk production $(\mathrm{kg} / \mathrm{d}), \mathrm{t}=$ week of lactation, and $\mathrm{a}, \mathrm{b}$, and $\mathrm{c}=$ parameters to be estimated. The data collected in this investigation was also used for the validation of the original DMI prediction 
model from the NRC (Nutrient..., 2001), in which the observed and predicted data were compared by the combined intercept test (Mayer et al., 1994). In the event the data did not fit the NRC (Nutrient..., 2001) model, the assessment of DMI using the structure of the model proposed by the NRC (Nutrient..., 2001) and its reparametrization was proposed, as follows: DMI $(\mathrm{kg} / \mathrm{d})=\left(\mathrm{a}^{*} \mathrm{FCM}+\mathrm{b} * \mathrm{BW}^{0.75}\right)+\left(1-\mathrm{e}^{\left(\mathrm{c}^{*}[\mathrm{WL}+\mathrm{d}]\right)}\right)$, where $\mathrm{FCM}=4 \%$ fat corrected milk, $\mathrm{BW}=$ body weight in $\mathrm{kg}, \mathrm{WL}=$ week of lactation, and a, b, c, and $\mathrm{d}=$ parameters to be estimated, using PROC NLIN of SAS (version 9.1).

To obtain the parameters of non-linear regression equations, the iterative process of the Marquardt algorithm and $t$ statistics were used to determine confidence intervals for the parameters $(1-\alpha=$ $0.95)$. To calculate asymptotic standard-deviation (A-SD), the maximum likelihood estimation method was used. To compare the models between different genetic groups, the test of model identity was used (Regazzi, 1999).

The statistical analyses for the DMI and DMd, as well as NEFAs, were performed using the multiple linear regression model $\mathrm{Y}=\beta_{0}+\beta_{1} \mathrm{D}_{1}+$ $\beta_{2} \mathrm{D}_{2}+\beta_{3} \mathrm{t}+\beta_{4}\left(\mathrm{t} * \mathrm{D}_{1}\right)+\beta_{5}\left(\mathrm{t} * \mathrm{D}_{2}\right)+\beta_{6} \mathrm{t}^{2}+$ $\beta_{7}\left(\mathrm{t}^{2} * \mathrm{D}_{1}\right)+\beta_{8}\left(\mathrm{t}^{2} * \mathrm{D}_{2}\right)+\epsilon$; To evaluate $\mathrm{BW}$ change throughout lactation, the statistical analyses were done by adjusting the data to the cube root model, modified to include the effect of genetic groups: $Y=D_{0}+\beta_{1} D_{1}+\beta_{2} D_{2}+\beta_{3} t+\beta_{4}\left(t * D_{1}\right)+$ $\beta_{5}\left(\mathrm{t}^{*} \mathrm{D}_{2}\right)+\beta_{6} \mathrm{t}^{1 / 2}+\beta_{7}\left(\mathrm{t}^{1 / 2} * \mathrm{D}_{1}\right)+\beta_{8}\left(\mathrm{t}^{1 / 2} * \mathrm{D}_{2}\right)+\beta_{9} \mathrm{t}^{3 / 2}+$ $\beta_{10}\left(t^{3 / 2} * D_{1}\right)+\beta_{11}\left(t^{3 / 2} * D_{2}\right)+\epsilon$, where $D_{1}$ and $D_{2}$ are dummy variables corresponding to the effects of the genetic groups, with $\mathrm{D}_{1}=0$ and $\mathrm{D}_{2}=0$ for HNE, $D_{1}=1$ and $D_{2}=0$ for HGU, $D_{1}=0$ and $D_{2}$ $=1$ for $\mathrm{HGI}$, and $\mathrm{t}$ was the variable regarding the effect of time over DMI, DMd, NEFA and BW. This study used $5 \%$ as the probability for the type I error. The analysis was carried out using the PROC REG of SAS (version 9.1). To compare the models between different genetic groups, the model identification test was used (Regazzi, 1999).

\section{RESULTS}

The genetic groups did not have an effect $(\mathrm{P}>0.05)$ on the DMI $(\mathrm{kg} / \mathrm{d}$ and $\% \mathrm{BW})$ and the DMd (Table 2). The regression equation parameters regarding DMI $(\mathrm{kg} / \mathrm{d})$ as a function of days in lactation were significant $(\mathrm{P}<0.001)$. The model was quadratic (Table 3), with a positive critical point or maxima. DMI as $\% \mathrm{BW}$ did not have significant linear or quadratic parameters $(\mathrm{P}>0.05)$, and this was also true for the DMd.

Since there was no genetic group effect on any DMI parameter, all of the data from the different genetic groups was compiled to develop a DMI equation for $\mathrm{F} 1$ cows. The original prediction model from the NRC (Nutrient..., 2001) did not explain DMI under tropical grazing conditions $(\mathrm{P}<0.001)$ according to the combined intercept test.

Table 2. Significance level of the genetic group effect $(\mathrm{P}-$ value) in multiple linear regression parameters of the days in lactation ${ }^{1}$

\begin{tabular}{|c|c|c|c|c|c|c|c|c|c|}
\hline \multirow[b]{2}{*}{ Item $^{2}$} & \multicolumn{3}{|c|}{ Intercept } & \multicolumn{3}{|c|}{ Linear effect } & \multicolumn{3}{|c|}{ Quadratic effect } \\
\hline & $\begin{array}{c}\text { HGI } x \\
\text { HNE }\end{array}$ & $\begin{array}{l}\text { HGU x } \\
\text { HNE }\end{array}$ & $\begin{array}{c}\text { HGI x } \\
\text { HGU }\end{array}$ & $\begin{array}{l}\text { HGI x } \\
\text { HNE }\end{array}$ & $\begin{array}{c}\text { HGU x } \\
\text { HNE }\end{array}$ & $\begin{array}{c}\text { HGI } x \\
\text { HGU }\end{array}$ & $\begin{array}{l}\text { HGI } x \\
\text { HNE }\end{array}$ & $\begin{array}{c}\text { HGU } \\
x \\
\text { HNE }\end{array}$ & $\begin{array}{c}\text { HGI } x \\
\text { HGU }\end{array}$ \\
\hline DMI, kg & 0.949 & 0.807 & 0.879 & 0.596 & 0.514 & 0.946 & 0.467 & 0.357 & 0.925 \\
\hline $\begin{array}{l}\text { DMI, } \\
\text { BW\% }\end{array}$ & 0.638 & 0.797 & 0.484 & 0.803 & 0.631 & 0.851 & 0.631 & 0.489 & 0.884 \\
\hline $\mathrm{DMd}, \mathrm{g} / \mathrm{kg}$ & 0.740 & 0.859 & 0.860 & 0.434 & 0.583 & 0.205 & 0.374 & 0.312 & 0.074 \\
\hline NEFA & 0.053 & 0.014 & 0.808 & 0.017 & 0.003 & 0.756 & 0.009 & 0.004 & 0.899 \\
\hline
\end{tabular}

${ }^{1}$ HGI - F1 Holstein x Gir; HGU - F1 Holstein x Guzerat; HNE - F1 Holstein x Nelore;

${ }^{2}$ DMI - Dry matter intake; DMd - Digestible dry matter; NEFA - Non-esterified fat acids, $\mathrm{mmol} / \mathrm{d}$

However, the model, when reparametrized (Figure 1), was adequate to predict the DMI of F1 cows under tropical pasture conditions $(\mathrm{P}=0.1407)$. After reparametrization of the model proposed by the NRC (Nutrient..., 2001), the final equation was obtained, as described: DMI $(\mathrm{kg} / \mathrm{d})=(0.6089 * \mathrm{FCM} 4 \%+0.0244$ $\left.* \mathrm{BW}^{0.75}\right)+\left(1-\mathrm{e}^{(-0.2919 *[\mathrm{WL}+5.5772])}\right)$, where: FCM4\%: fat corrected milk; BW: body weight; and WL: week of lactation. 
Intake, milk production...

Table 3. Estimated parameters in multiple linear regression models of the days in lactation ${ }^{1}$

\begin{tabular}{|c|c|c|c|c|c|c|c|c|c|}
\hline \multirow[b]{2}{*}{ Item $^{2}$} & & \multicolumn{3}{|c|}{ Regression parameters } & \multirow[b]{2}{*}{$\mathrm{R}-\mathrm{SD}$} & \multirow[b]{2}{*}{$\mathrm{R}^{2}$} & \multirow[b]{2}{*}{$P$ - value } & \multicolumn{2}{|c|}{ Critical point } \\
\hline & & Intercept & $\mathrm{t}$ & $t^{2}$ & & & & $\begin{array}{c}\text { Position } \\
\text { (day) }\end{array}$ & $\begin{array}{l}\text { Expected } \\
\text { response }\end{array}$ \\
\hline $\begin{array}{l}\text { DMI, } \\
\mathrm{kg} / \mathrm{d}\end{array}$ & & 12.9566 & 0.0215 & -0.000267 & 1.84 & 0.3499 & $<0.0001$ & 40 & 13.34 \\
\hline $\begin{array}{l}\text { NEFA } \\
\text { HNE }\end{array}$ & - & 0.87797 & -0.01326 & 0.00005658 & 0.14 & 0.4381 & $<0.0001$ & 117 & 0.1010 \\
\hline $\begin{array}{l}\text { NEFA } \\
\text { HGU }\end{array}$ & - & 0.54187 & -0.00492 & 0.00001615 & 0.14 & 0.4381 & $<0.0001$ & 151 & 0.1671 \\
\hline $\begin{array}{l}\text { NEFA } \\
\text { HGI }\end{array}$ & - & 0.63704 & -0.00807 & 0.00003313 & 0.14 & 0.4381 & $<0.0001$ & 122 & 0.1456 \\
\hline
\end{tabular}

${ }^{1} t$ - linear effect of the time; $t^{2}$ - quadratic effect of the time; R-SD - residual standard deviation;

${ }^{2}$ NEFA - Non esterified fat acids, mmol/d; HGI - F1 Holstein x Gir; HGU - F1 Holstein x Guzerat; HNE - F1

Holstein x Nelore

The parameters of 3 different lactation curves for HGI, HGU and HNE (Table 4) were developed, as follows: HGI $=17.2667 * \mathrm{t}^{0.0652} * \mathrm{e}^{-0.00424 \mathrm{t}}$; $\mathrm{HGU}=18.1470 * \mathrm{t}^{0.0332} * \mathrm{e}^{-0.00408 \mathrm{t}} ;$ and $\mathrm{HNE}$ $=14.2836 * \mathrm{t}^{0.1059} * \mathrm{e}^{-0.00552 \mathrm{t}}$ (Figure 1). The lactation curve for HGI cows showed that there was a greater milk production during most of lactation, in comparison to the other groups; its peak lactation was discrete and coincided with those of the HGU cows. The HGI cows had peak production on day 15 , producing $19.33 \mathrm{~kg} / \mathrm{d}$, and the HGU cows had peak production on day 8 , producing $19.08 \mathrm{~kg} / \mathrm{d}$. The milk production sustained by HGI cows on day 305 , in proportion to peak production, was of $35.58 \%(6.87 \mathrm{~kg} / \mathrm{d})$, which was a little higher than that of HGU cows $(33.60 \%$ and $6.41 \mathrm{~kg} / \mathrm{d})$. The projected total production on day 305 of lactation for HGI cows was greater $(3938 \mathrm{~kg})$ than HGU cows $(3713 \mathrm{~kg})$, because of its lower rate of decline in production.

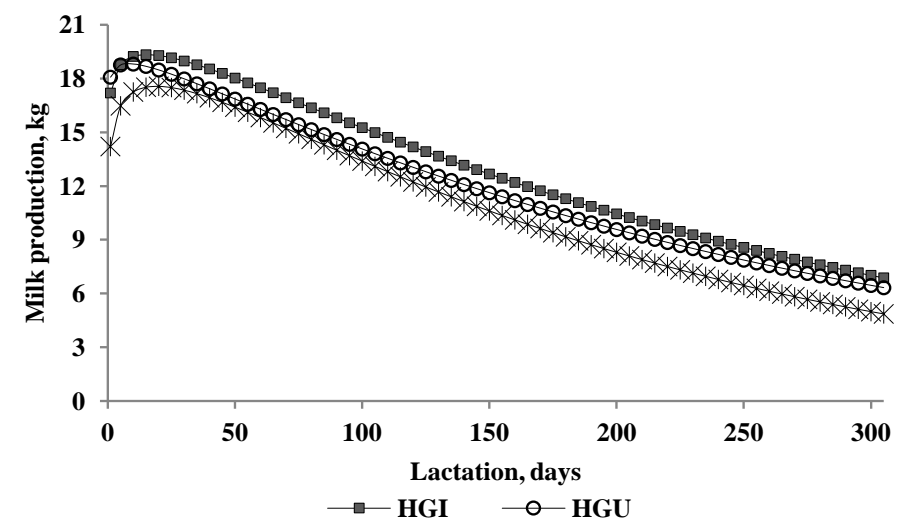

Figure 1. Lactation curves of the F1 Holstein $\mathrm{x}$ zebu cows from different genetic groups as follows: HGI - Holstein x Gir: $\mathrm{Y}=17.2667 * \mathrm{t}^{0.0652} * \mathrm{e}^{-0.00424 t}$; HGU - Holstein x Guzerat: $\mathrm{Y}=18.1470 * \mathrm{t}^{0.0332} * \mathrm{e}^{-0.00408 \mathrm{t}}$ and HNE - Holstein $x$ Nelore: $\mathrm{Y}=14.2836 * \mathrm{t}^{0.1059} * \mathrm{e}^{-0.00552 \mathrm{t}}$

The HNE cows had, in general, lower cumulative milk production than the other groups $(3335 \mathrm{~kg}$ at day 305), with discrete peak lactation on day 19. Its maximum production was $17.56 \mathrm{~kg} / \mathrm{d}$, and it had the lowest lactation persistence among the three groups, sustaining only $27.68 \%$ of peak production on day 305 of lactation. This group also had the lowest initial production, as can be observed when the intercepts of the equations are compared (Table 4). The NEFA content (Table $2)$ varied with genetic group $(\mathrm{P}<0.05)$, presenting 3 different equations $(\mathrm{P}<0.001)$ as a function of days in lactation (Table 3 ). Thus, an equation was developed for each group: HGI $=0.63704$ $0.00807 * \mathrm{t}+0.00003313 * \mathrm{t}^{2} ; \mathrm{HGU}=0.54187-$ $0.00492 * \mathrm{t}+0.00001615 * \mathrm{t}^{2} ;$ and HNE $=0.87797$ $-0.01326 * \mathrm{t}+0.00005658 * \mathrm{t}^{2}$. The cows birthed by Nelore dams had greater mobilization of body 
reserves during early lactation, observed by the intercept of the equation. Within 117 days, this group reached a lower level of mobilization compared to the other genetic groups. The cows birthed by Guzerat and Gir dams had lower
NEFA in early lactation and maintained a slower decline in NEFA during lactation, reaching a minimum NEFA at day 151 and 122, respectively. From then on, all of the groups had a resurge of NEFA contents in plasma.

Table 4. Estimated parameters for the Wood (1967) model and descriptive statistics of the observed data

\begin{tabular}{cccc}
\hline \multirow{2}{*}{ Parameters } & \multicolumn{2}{c}{ Wood (1967) model for genetic groups ${ }^{1}$} \\
\cline { 2 - 4 } & HGI & HGU & HNE \\
a & $17.2667 \pm 2.5145$ & $18.1470 \pm 1.2313$ & $14.2836 \pm 2.0699$ \\
$\mathrm{~b}$ & $0.0652 \pm 0.0421$ & $0.0332 \pm 0.0209$ & $0.1059 \pm 0.0444$ \\
$\mathrm{c}$ & $0.00424 \pm 0.0004$ & $0.00408 \pm 0.00028$ & $0.00552 \pm 0.00057$ \\
\hline
\end{tabular}

\begin{tabular}{ccccccccc}
\hline & \multicolumn{7}{c}{ Descriptive statistics } \\
\cline { 2 - 8 } & Average & Median & Mode & Max & Min & SD & CV & $\mathrm{n}$ \\
\hline Days in lactation & 121.30 & 113.0 & 196 & 287 & 1 & 63.9 & 52.6 & 966 \\
Milk Yield, kg & 13.35 & 13.5 & 15 & 24 & 3 & 3.8 & 28.8 & 966 \\
\hline
\end{tabular}

${ }^{1}$ HGI - F1 Holstein x Gir; HGU - F1 Holstein x Guzerat; HNE - F1 Holstein x Nelore; Wood (1967) model: $\mathrm{Y}=\mathrm{at}^{\mathrm{b}} \mathrm{e}^{\mathrm{ct}}$

These data may be assessed in combination with those of BW change (Table 5 and Figure 2), because there was a difference in the intercept of the BW change curve for the 3 genetic groups, in addition to describing a second phase of BW loss after day 150 of lactation, a period that coincided with a reduction in the availability of digestible $\mathrm{DM}$ in tropical pasture (after 5 months in pasture).

Table 5. Estimated parameters of the cube root model used to fit the weight variation data throughout days in lactation, different genetic group effects $(P$-value $)$ and descriptive statistics of the observed data

\begin{tabular}{|c|c|c|c|c|c|c|c|}
\hline \multirow[t]{2}{*}{ Iten $^{2}$} & \multicolumn{7}{|c|}{ Regression parameters $^{T}$} \\
\hline & intercept & $\mathrm{t}$ & $t^{1 / 2}$ & $t^{3 / 2}$ & R-SD & $\mathrm{R}^{2}$ & $P-$ value \\
\hline HGI & 607.70 & 3.6957 & -32.4659 & -0.1352 & 45.92 & 0.2379 & $<0.0001$ \\
\hline $\mathrm{HGU}$ & 664.73 & 3.6957 & -32.4659 & -0.1352 & 45.92 & 0.2379 & $<0.0001$ \\
\hline \multirow[t]{3}{*}{ HNE } & 657.42 & 3.6957 & -32.4659 & -0.1352 & 45.92 & 0.2379 & $<0.0001$ \\
\hline & \multicolumn{7}{|c|}{ Genetic group effects $(P-$ value $)$} \\
\hline & Intercept & \multicolumn{2}{|c|}{$\mathrm{t}$} & \multicolumn{2}{|c|}{$t^{1 / 2}$} & \multicolumn{2}{|c|}{$\mathrm{t}^{3 / 2}$} \\
\hline HGI x HNE & $<0.0001$ & \multicolumn{2}{|c|}{0.0877} & \multicolumn{2}{|c|}{0.0616} & \multicolumn{2}{|c|}{0.1230} \\
\hline HGU x HNE & 0.1913 & \multicolumn{2}{|c|}{0.0716} & \multicolumn{2}{|c|}{0.0716} & \multicolumn{2}{|c|}{0.0650} \\
\hline HGI x HGU & 0.0253 & \multicolumn{2}{|c|}{0.6214} & \multicolumn{2}{|c|}{0.4447} & \multicolumn{2}{|c|}{0.8290} \\
\hline & \multicolumn{7}{|c|}{ Descriptive statistics } \\
\hline & average & median & $\max$ & $\min$ & SD & $\mathrm{CV}$ & $\mathrm{n}$ \\
\hline Days in lactation & 137.1 & 140 & 280 & 1 & 68.3 & 49.8 & 205 \\
\hline Body weight, kg & 552.0 & 554 & 667 & 441 & 51.9 & 9.4 & 205 \\
\hline
\end{tabular}

${ }^{\mathrm{t}} \mathrm{t}$ - linear effect; $\mathrm{t}^{1 / 2}$ - cube effect; $\mathrm{t}^{3 / 2}-$ cube root effect; R-SD - residual standard-deviation;

${ }^{2}$ HGI - F1 Holstein x Gir; HGU -F1 Holstein x Guzerat; HNE - F1 Holstein x Nelore;

There was a difference in the initial BW of the 3 genetic groups (Table 5 and Figure 2) and in the degree of mobilization of NEFA. The HGI and HGU cows had a greater preservation of blood NEFA than the HNE group, at week 7 of lactation, which was the week the cows had the lowest BW since the beginning of lactation.
Despite the different intercepts obtained for the BW change curves, it was observed that the remaining parameters were the same for the different groups (Table 5). Thus, an intercept was defined for each group: HGI $=657.42+$ $3.6957 * \mathrm{t}-32.4659 * \mathrm{t}^{1 / 2}-0.1352 * \mathrm{t}^{3 / 2} ; \mathrm{HGU}=$ $664.73+3.6957 * \mathrm{t}-32.4659 * \mathrm{t}^{1 / 2}-0.1352 * \mathrm{t}^{3 / 2} ;$ and $\mathrm{HNE}=607.70+3.6957 * \mathrm{t}-32.4659 * \mathrm{t}^{1 / 2}-$ 
$0.1352 * \mathrm{t}^{3 / 2}$. This means that all of the genetic groups had the same rate of $\mathrm{BW}$ change throughout lactation.

Thus, the HGI cows, with lower initial weights, had the greatest weight loss when compared to their initial weight, losing $15.25 \%$ of their total initial BW through week 18 of lactation, in comparison to $14.08 \%$ for the HNE and $13.88 \%$ for the HGU groups. The HNE cows, although showing less $\mathrm{BW}$ loss in relation to their initial weight, had a high concentration of circulating NEFAs in the first days of lactation, followed by a sharp reduction, reaching a basal level of 0.101 $\mathrm{mmol} / \mathrm{ml}$ on day 117 of lactation. HNE circulating NEFA reached $88.5 \%$ of the initial concentration, whereas the HGU and HGI reached $69.2 \%$ and $76.9 \%$, of their initial concentration, respectively.

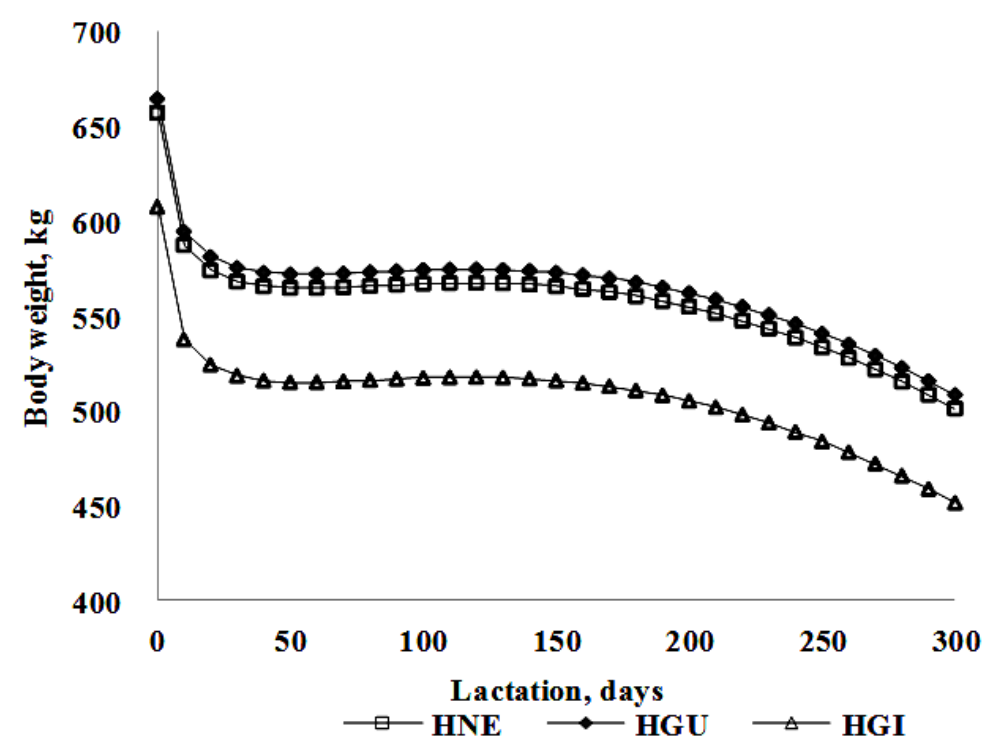

Figure 2. Body weight variation curves of the Holstein $\mathrm{x}$ zebu cows from different genetic groups as follows: HGI - Holstein $x$ Gir $=607.70+3.6957 * \mathrm{t}-32.4659 * \mathrm{t}^{1 / 2}-0.1352 * \mathrm{t}^{3 / 2}$; HGU - Holstein $\mathrm{x}$ Guzerat $=664.73+3.6957 * \mathrm{t}-32.4659 * \mathrm{t}^{1 / 2}-0.1352 * \mathrm{t}^{3 / 2} ;$ HNE - Holstein $\mathrm{x}$ Nelore $=657.42+3.6957 * \mathrm{t}$ $-32.4659 * \mathrm{t}^{1 / 2}-0.1352 * \mathrm{t}^{3 / 2}$.

\section{DISCUSSION}

According to Oldenbroek and Jansen (1978), different breeds or genetic groups together, under grazing systems, have few differences in their grazing behavior. Feeding behavior is intrinsically linked to the nature of the food available. Under a grazing system, food must be searched for and gathered by the cow, which turns feeding into a challenge, and other factors associated with pasture characteristics become key factors in determining intake.

Dry matter intake had a maximum value estimated at $13.34 \mathrm{~kg}$ at 40 days of lactation, a fact that seems to be closely connected to the characteristics of the pasture available. As shown in Table 1, the pasture had lower NDFap content in the extrusa, around day 42 , which coincided with the peak intake for the cows in this experiment. During this period, the pasture also had greater CP and NFCap content and a lower DM content, despite the lower pasture allowance until day 40 of lactation (Table 1).

Similar to intake, there were no effects of the genetic group on DMd. According to Forbes (1995), the intake level of an animal is among the most important factors that directly affect feed digestibility. This relationship follows an inversely proportional pattern; that is, the lower the intake level, the greater the digestibility of the feed, due in large part to reduction of the rumen passage rate. As there were no effects of the different genetic groups for DMI in this investigation, digestibility would be expected to follow this behavior because the animals were exposed to the same diet. 
With the use of new parameters $(\mathrm{a}=0.6089 \pm$ $0.0738 ; \mathrm{b}=0.0244 \pm 0.00764 ; \mathrm{c}=-0.2919 \pm$ $0.3774 ; \mathrm{d}=5.5772 \pm 10.4701)$ for the model proposed by the NRC (Nutrient..., 2001), DMI curves can be obtained for different periods of lactation for $\mathrm{F} 1$ cows with different milk production and BW (Figure 1). There was a peak in the curve at approximately 6 week of lactation, when DMI plateaued, remaining constant until the end of lactation. Peak DMI was similar to that proposed by the NRC (Nutrient..., 2001) for multiparous cows, which showed that the structure of this model was adequate to predict intake based on the inherent characteristics of the animal, just by reparametrizing the model, even with the large differences in the feeding systems to which the animals were subjected.

Using the model by Wood (1967), peaks of lactation were projected for the different genetic groups. According to Keown et al. (1986) there is a tendency for delayed peak lactation at higher level of production. Despite the small difference in the number of days, the HGI cows took longer to reach the peak. Nevertheless, this time interval to peak was quite different from that described by Wood (1967), who reported it to be from 5 to 6 weeks, for intensive systems in temperate climates, with Holstein cows that had greater production and greater lactation persistence.

These two crosses also had similar production at the end of lactation, when the milk production was stabilized at the lowest level of production. However, it is possible to affirm that lactation persistence of HGU cows was a little lower than HGI cows. Branton et al. (1974) suggested that the lower milk production, in pasture-based systems, is the main factor that affects persistence in lactation; that is, the forage allowance is a limiting factor over the dry season, and it is not exactly a climate factor.

Studies in the literature that show the performance of crossbred HNE are non-existent to date. However, some studies may be found for lactation curves of pure breed Nelore cows, with emphasis on calf performance. Few studies measured milk production during the entire lactation period, showing a linear decrease in milk production and an absence of peak lactation (Alencar, 1988 and Rosado, 1991).

According to Buckley et al. (2000), the first stage of increased BW loss around 6 weeks was due to expelling the fetus, placenta and other uterine contents, followed by the gradual decrease in $\mathrm{BW}$ because of the mobilization of adipose tissues. For Bauman and Currie (1980), in the first month of lactation, the adipose tissue energy may contribute to approximately $33 \%$ of milk production. The catabolism of adipose tissue may support the production of 120 to $550 \mathrm{~kg}$ of milk during the first weeks of lactation. HGI and HGU cows had greater preservation of circulating NEFAs than cows from the HNE group, even after reaching the minimum value during lactation. Rennó et al. (2006), in a review of several studies, observed that higher geneticmerit cows for milk production showed limited response of adipose tissue to the anti-lipolytic agents, resulting in an increased rate of lipolysis.

Regarding the HNE cows, there was a drop in the level of circulating NEFAs to $88.5 \%$ of the initial concentration. This was probably due to the temperament of this group of cows postpartum. Mourão et al. (1997), evaluating the temperament of different zebu breeds, observed a worse temperament for the Nelore animals. The animals classified as having the worst temperaments are more excitable, ingest less food, are more agitated, do not adapt easily to new situations, and are more difficult to manage (Grandin and Deesing, 1998).

Increased NEFA mobilization at the beginning of lactation, however, was not reflective of greater BW loss. This phenomenon was possible because, as reported by Andrew et al. (1994), dairy cows can change body composition in early lactation, mobilizing close to $40 \%$ of its tissues, without showing significant changes in $\mathrm{BW}$, due to a rapid increase in DMI in the gastrointestinal tract. In contrast, all of the genetic groups studied had BW loss after 150 days in lactation, associated with a change in circulating NEFAs in the blood. This was probably due to the low quality of pastures found in this stage. 


\section{CONCLUSIONS}

The peak DMI, estimated by the reparametrized equation from the NRC (2001), occurred during the sixth week of lactation, when there was the stabilization of DMI from pasture. Nonetheless, the cows went through a negative energy balance phase during the seventh week because of the characteristics of the tropical pasture. The HGI group presented the greatest cumulative milk production at 305 days.

\section{REFERENCES}

ALENCAR, M.M. Productive Performance of femelas canchim and nelore breed. Rev. Bras. Zootec., v.17, p.411-420, 1988.

ANDREW, S.M.; WALDO, D.R.; ERDMAN, R.A. Direct analysis of body composition of dairy cows at three physiological stages. J. Dairy Sci., v.77, p.3022-3033, 1994.

BAUMAN, D.E.; CURRIE, W.B. Partitioning of nutrients during pregnancy and lactation: A review of mechanisms involving homeostasis and homeorhesis. J. Dairy Sci., v.63, p.1514$1529,1980$.

BRANTON, C.; RIOS, G.; EVANS, D.L. et al. Genotype-climatic and other interaction effects for productive responses in Holsteins. J. Dairy Sci., v.57, p.833-841, 1974.

BUCKLEY, F.; DILLON, P.; RATH, M. et al. The relationship between genetic merit for yield and live weight, condition score, and energy balance of spring calving holstein friesian dairy cows on grass based systems of milk production. J. Dairy Sci., v.83, p.1878-1886, 2000.

CASALI, A.; DETMANN, E.; VALADARES FILHO, S.C. et al. Influence of incubation time and particles size on indigestible compounds contents in cattle feeds and feces obtained by in situ procedures. Rev. Bras. Zootec., v.37, p.335342, 2008.

DETMANN, E.; VALADARES FILHO, S.C. et al. On the estimation of non-fibrous carbohydrates in feeds and diets. Arq. Bras. Med. Vet. Zootec., v.62, p.980-984, 2010.

FORBES, J.M. Voluntary food intake and diet selection in farm animals. Oxon: CAB International, 1995.
GRANDIN, T.; DEESING, D. Behavioral genetics and animal sciences. In: GRANDIN, T. (Ed). Genetics and behavioral of domestic animals. San Diego: Acad. Press, 1998. p. 341356.

KEOWN, J.F.; EVERETT, R.W.; EMPET, N.B. et al. Lactation curves. J. Dairy Sci., v.69, p.769$781,1986$.

LICITRA, G.; HERNANDEZ, T.M.; VAN SOEST, P.J. Standardization of procedures for nitrogen fractionation of ruminant feeds. Anim. Feed Sci. Technol., v.57, p.347-358, 1996.

MAYER, D.G.; STUART, M.A.; SWAIN, A.J. Regression of real-world data on model output: An appropriate overall test of validity. Agric. Syst., v.45, p.93-104, 1994.

MCMENIMAN, N.P. Methods of estimating intake of grazing animals. In: REUNIÃO ANUAL DA SOCIEDADE BRASILEIRA DE ZOOTECNIA, 34., 1997, Juiz de Fora. Anais... Juiz de Fora:1997. p.131-137.

MERTENS, D.R. Gravimetric determination of amylase-treated neutral detergent fiber feeds with refluxing in beakers or crucibles: Collaborative study. J. AOAC Inst., v.85, p.12171240, 2002.

MOURÃO, G.B.; BERGMANN, J.A.G.; FERREIRA, M.B.D. Medidas lineares, pelagem e temperamento em fêmeas mestiças F1. Cad. Tec. Esc. Med. Vet. Zootec., v.18, p.61-70, 1997.

MYERS, W.D.; LUDDEN, P.A.; NAYIGIHUGU, V. Technical note: A procedure for the preparation and quantitative analysis of samples for titanium dioxide. J. Anim. Sci., v.82, p.179-183, 2004.

NUTRIENT requirements of Dairy Cattle, 7.ed. Washington: National Academy Press, 2001.

OFFICIAL methods of analysis - AOAC. 15. ed. Washington: Assoc. Off. Anal. Chem., 1990.

OLDENBROEK, J.K.; JANSEN, A.A.M. The effect of the grazing behaviour of a breed on the performance of another breed, when they are grazing together. Zeit. für Tierzüch. und Züchtungsb., v.95, p.132-139, 1978.

PEREIRA., J.C.C. Fundamentos de bioclimatologia aplicada à produção animal. Belo Horizonte: FEPMVZ, 2005. 
REGAZZI, A.J. Test for parameter equality in nonlinear regression models. Rev. Ceres, v.46, p.383-410, 1999.

RENNÓ, F.P.; PEREIRA, J.C.; SANTOS, A.D.F. et al. Effects of body condition at calving on milk yield and composition, lactation curve and body reserve mobilization of Holstein cows. Arq. Bras. Med. Vet. Zootec., v.58, p.220233, 2006

ROSADO, M.L. Características reprodutivas, produtivas e biométricas de fêmeas Nelore e F1
europeu-Nelore. 1991. 55f. Dissertação (Mestrado em Zootecnia) - Departamento de Zootecnia, Universidade Federal de Viçosa, Viçosa.

WOOD, P.D.P. Algebraic model of the lactation curve in cattle. Nature. v.216, p.164-165, 1967. 